洪水流出予測における準線形化手法の適用に関する分析

Study on a Quasilinearization Technique for Flood Run-off

(侏日水コン 正員 森 野 彰 夫
(侏日水コン 正員蔵重 俊 夫

1. はじめに

本稿は, 著者ら年ぞの収束性改善を試みた準線形化によるパラメーター決定アルゴリズムをダム流入量予 測を目的とした洪水流出予測モデルに適用し，その有効性を明らかにしたものである。

洪水流出の予測は, 豪雨や出水が想定される場合に, その規模, 発生時刻を予測するものであり, 冶水事 業が十分に行なわれていない地域ではその代替事業として, 一方, 冶水事業が十分に行なわれている地域で も計画超過洪水に対する対策として, 又ダム，堰等の河川管理施設の操作情報として必要であるてとは言う までもない。

本稿では, このうち河川上流に位置するダム流入量予測に対し，準線形化手法を用いた流出計算法の改良 を試みるとととした。具体的には，ダム流入量を予測する場合，予測モデルのパラメーターが不適当な場合 には, 予測誤差は当然大きくなり, 洪水時に貯水容量をより有効に利用するという立場からは望ましくない。 てのため, てのような誤差を縮めるための一つの方法として, 実測の降雨 - 流出量の関係に合うようモデル パラメーターを時々刻々変えて（逆算して）いく方法が考えられている。本稿は，てのプロセスに準線形化 によるパラメーター決定アルゴリズムを援用し, 洪水流入量の大きさや洪水の時間的経過に従がって予測モ デルの運用を行なうととの有効性を確認するとととした。

まず 2.では, 準線形化によるパラメーター決定問題を対象に, 洪水予測手法としての有効性を主としてパ ラメーター決定アルゴリズムの面から考察し, 本稿での目的を明らかにする。ついで, 3.では実流域を対象 に本モデルの運用を行ない, 洪水時に必要となる予測時間, 予測精度を考慮したモデルの運用方法について 検討した結果を示す。

2. 洪水予測における準線形化手法の適用について

\title{
2-1 準線形化と最適化手法
}

準線形化は, 非線形汎関数方程式の数值解法の一つであり, 非線形常微分方程式を線形化するてとにより パラメーター決定問題を線形常微分方程式の初期值決定問題のくり返し過程として取り扱う。そしてその有 効性は未知のパラメーターを含む非線形常微分方程式のパラメーター決定において特に発揮される。

そして，ての手法について以下のような点を利点としてあげるてとができる。

(1)非線形微分方程式の直接的な求解を必要としないので計算が単純化される。

(2)パラメーター以外の変数について, その初期条件が与えられない場合や, 信頼性に欠ける場合について も，その初期值をパラメーターと同様に決定できる。

(3)くり返し過程は 2 次の収束速度を持つととが示され計算時間も比較的短く, 初期仮定解の適切な設定に より, 試行錯誤的要素を必要としない,

しかしながら，準線形化によるパラメーター同定は，最小二乗法を最適化手法として用いたアルゴリズム による限り，収束性が覀く実用性に欠ける点が問題として指摘されだ。このため，著者らは収束性を改善す る一つの方法として予めパラメーターに制約を設け，収束計算過程で解が発散していくととを防ぐと同時に 微分方程式の求解過程や, 解の最適化過程でのオーバーフローによる計算中断を防ぐことを考え, 最適化手 法として計算速度の早い制約条件付最適化手法としてのコンプレックス法を用いたアルゴリズムを採用する とととした。 


\section{$2-2$ 洪水流出予測モデルの運用方法}

ダム流入量予測に際しては, 流入規模と共に流出総量も又情報として重要である。そしててのてとは有効 流出量や流域の貯留残高といった要素も推定対象となり，降雨状況や流域条件をもパラメーターとして推定 するととが必要となる。また, ダムは河川の中・上流部に設けられ, 集水面積も数百Km²下場合が多いた め, 流入量予測の計算方法としても貯留関数法等に代表される流出計算が一般に行なわれる。しかしな がら, 貯留関数法等を用いて流域流出量を予測する場合には, その定数が適正かどうかが予測精度に大きく

影響する。

貯留関数法等に代表される流出計算法は, 一般に洪水時の流出現象の全般（小流量～大流量, 洪水の前半 〜後半, 台風性〜前線性の洪水等）にわたって必ずしも精度よく表現できるものではない。てのため, 生じ る予測誤差を縮めるための一つの便宜法として, 洪水期間中, 実測の流域降雨〜ダム流入量の関係が再現で きるようモデル定数を時々刻々変えて（逆算して）いく方法がとられている。すなわち, 洪水流出量の大き さや洪水の時間的経過に従がって, きめ細かく予測モデルを運用していくという方法である。

本稿では，上述のてのプロセスに準線形化によるパラメーター決定アルゴリズムを適用し， 2 - 1 で述べ たろつの利点を最大限活用するととにより洪水時におけるダム流入量予測の精度向上を図るとととした。困 - 1 に準線形化手法を用いたダム流入量予測モデルの運用方法を示す。同図に示すように，モデル運用に際 しては時々刻々入手できる降雨ならびに流入量データを用い，その都度モデルパラメーターの決定を行ない， 必要とする予測期間までの将来流入量を推定していくという手順を踏むとととした。このような運用方式は 現行のダム操作時にわいても用いられているが，パラメーターの決定に人為的な試行錯誤が入るため必ずし も効率よく運用されているとは言い難い。このため, 本稿ではこのプロセスを準線形化によるアルゴリズム の援用により自動化するとともに予測精度, 予測に要する時間をさらに改善, 短縮するための検討を合わせ て行なうととを目的とした。

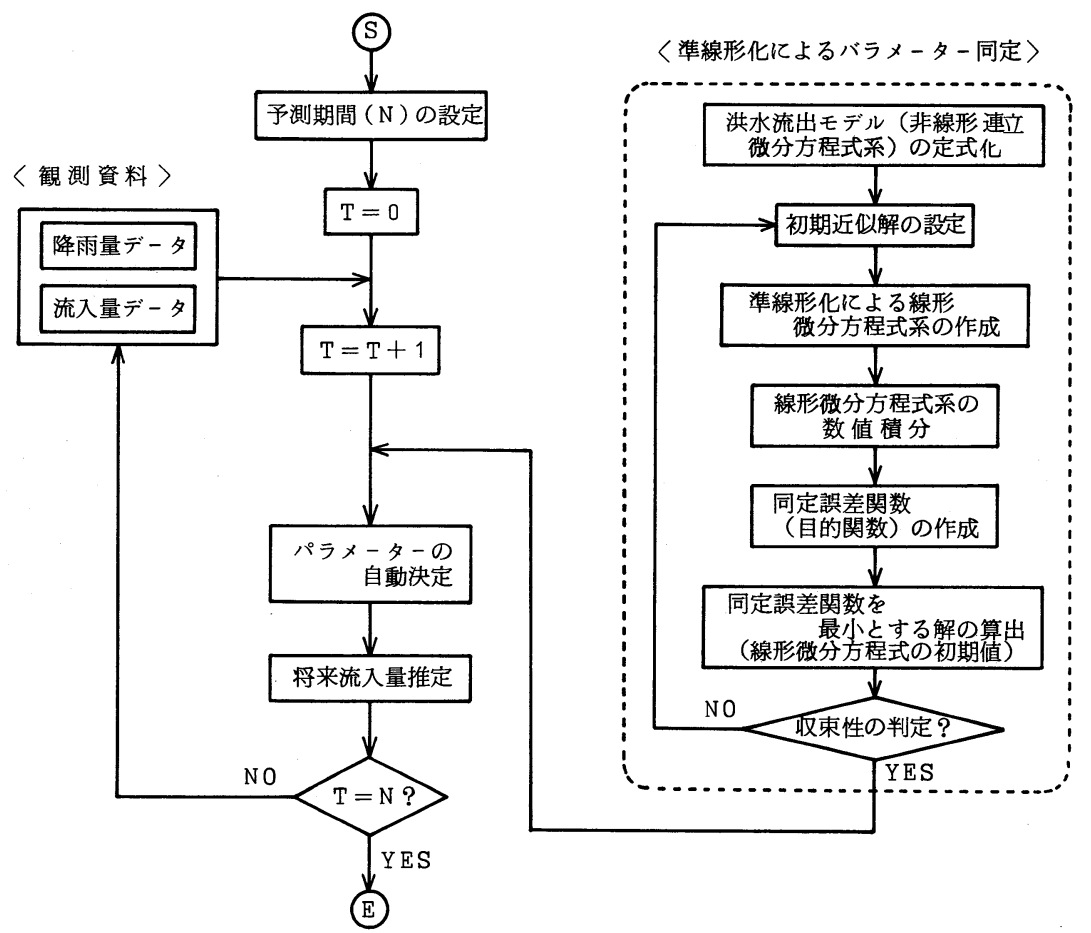

図-1 準線形化手法を用いた予測モデルの運用方法 


\section{3. 実流域にわける適用結果}

\section{3-1 流入量予測モデル}

ダム流入量の予測に際しては, ダム地点上流域における流域平均雨量を入力とし，ダム流入量（流域から の流出量）を推定する流出計算法を予測モデルとして用いるとととした。そして雨量データについては別途 降雨予測により将来の降雨量が与えられるものとし，ての予測降雨量を用いて将来の岁流入量を推定してい くとととした。

四ー2にダム流入量の予測モデルを示す。対象としたダム地点は上流域の流域面積が $100 \mathrm{Km}^{2}$ であり,一 般にてのような流域からの流出量の推定には貯留関数法が用いられている。ててでは, 貯留関数法にわける 有効降雨の概念がさらに物理的なメカニズムとして把握できるよう降雨分離サブモデルを通した，地下損失 を有するタンクモデルとして流出現象を記述するとととした。）

設定した降雨分離モデル式を(1)(2)式に示す。

<降雨分離モデル>

$$
\begin{aligned}
& r_{1}=\left(1-\frac{a_{1}}{1+a_{2} \cdot r f}\right) \cdot r \quad \text { (1) } \\
& r_{2}=r-r_{1} \quad \text { 但し, } r_{1} \leqq r
\end{aligned}
$$

とてに,

$\boldsymbol{r} ;$ 総降雨量 $(\boldsymbol{m m} / \boldsymbol{h r})$

$r_{1}$; 直接流出に寄与する降雨量 $(m m / h r)$

$r_{2} ;$ 地下水流出に寄与する降雨量 $(m m / h r)$

$r_{f}$; 累加雨量 $(m m), a_{1}, a_{2}$; 定数

なお, (1)式の係数 $\left(1-\frac{a_{1}}{1+a_{2} \cdot r f}\right)$ は,

貯留関係法で使用される 1 次流出率を $\left(1-a_{1}\right)$

と記述し, 累加雨量 $r f$ が大きくなれば飽和流出

率（こてでは，1.0と仮定する。）に漸近して
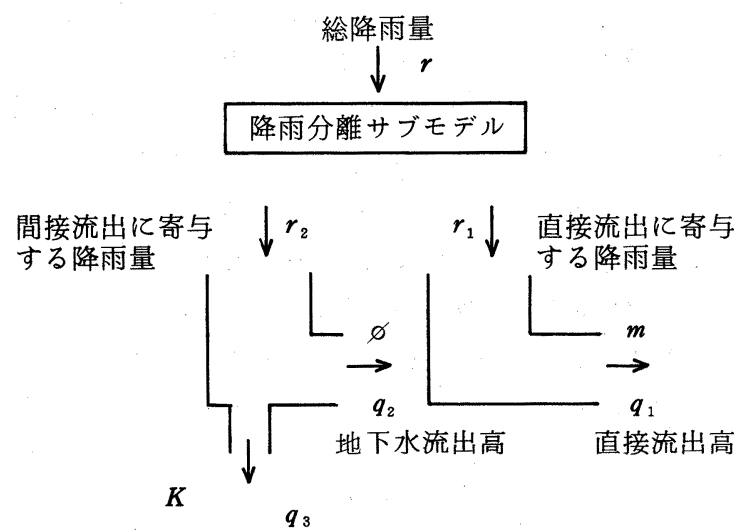

地下損失高

困－2ダム流入量予測モデル

いくというプロセスをモデル表現したものである。したがって，貯留関数法を用いた予測モデルに比べ，よ り現実の流出メカニズムを適切に表わしたものと考えられる。

直接流出，間接流出の各流出を記述するモデル式は，以下の(3)〜 (7)式である。

〈直接流出サブモデル>

$$
\begin{aligned}
& d S_{1} / d t=r_{1}-q_{1} \\
& S_{1}=K \cdot q_{1} p=1 / m \cdot q_{1} p
\end{aligned}
$$

<間接流出サブモデル >

$$
\text { ことに, }
$$

$$
\begin{aligned}
& d S_{2} / d t=r_{2}-q_{2}-q_{3} \\
& q_{2}=\varnothing \cdot S_{2} \\
& q_{3}=K \cdot S_{2}
\end{aligned}
$$

$q_{1}$; 直接流出高 $(m m / h r), q_{2}$; 地下水流出高 $(m m / h r), q_{3}$; 地下損失高 $(m m / h r)$

$S_{1}$; 直接流出高に対する貯留高 $(\mathrm{mm}), S_{2}$; 地下水流出高に対する貯留高 $(\boldsymbol{m m})$

$m, \varnothing, K, P$; 定数 $(P=0.6)$

3 - 2 予測モデルの運用結果

最適化手法としてコンプレックス法を組合せた準線形化によるパラメーター決定アルゴリズムの適用性を 調べるため, 洪水期間 2 日間（48時間）の全データを用い, まずアルゴリズムの妥当性を検証するてとと した。図ー 2 に示したようにモデルにおいて同定すべき変数は， $m, \varnothing, K, a_{1}, a_{2}$ の 5 つのパラメーターと流 出高の初期条件 $q_{1}(0), q_{2}(0)$ の計 7 つであり, 各変数の制約条件は表-1のように設定した。さらに, 目的関 数はハイドログラフの形状を対象とした全期間にわたって一致させるという立場から実測流入量と推定值の毎日 の相対二乗誤差最小とし，5\%の許容誤差内で全てのパラメーターが 3 回くり返されたとき収束とみなした。 
以上の条件下でのダム流入量の推定結果を図 - 3 亿示す。洪水期間の初期及び減衰期において若干誤差が 大きく現われているが, 総流入量については実測值 $392 \mathrm{~mm}$ に対し, $369 \mathrm{~mm}$ とい5 $6 \%$ 以内の誤差で推定が可 能であるととがわかった。

しかしながら，実際のダム操作時においては，上述のように全てのデータが得られているわけではない。 てのため,つぎ時々刻々入手できる降雨, 流量データに対し、デー夕を蓄積するととによってどの程度の 精度で将来流入量の推定が可能であるかについて検討するとととした。罒ー4 (1)(2)(3)に降雨開始から各々8, 16.24時間までの流量データを用い，それ以降のダム流入量を予測した結果を示す。各ケースでの特徵は以 下の通りであり, ダム操作に際しては少なくとも流量の立上り時刻までのデータを用いて将来流入量の予測 を行なうことが望ましいと判断できる。

i）降雨開始 8 時間までのデータを用いた場合（図ー4(1)）

いわゆる一次流出率が卓越して現われる期間であり,ての期間のデータを用いての予測は, ダム流入 量のピークを過小に予測してしまう結果となる。

ii）降雨開始 16 時間までのデータを用いた場合（図ー4(2)）

降雨の 1 番目のピークが通過した後の, いわゆる流出現象が飽和流出率となる時期である。このため 同定されるパラメーターも直接流出の卓越する現象をよく記述しており, 流入量が増大する時期の予測結 果も门のケースに比べるとかなり良好となる。

iii）降雨開始 24 時間までのデータを用いた場合（図ー4(3)）

降雨量のピークが通過する時点までのデータを用いた場合であり，予測した流量ハイドログラフの形 状も安定している。但し, ダム操作等を対象とした流入量予測に際しては, 用いたデータ以降の予測精 度が問われるのであって, 入手済期間内での予測精度の良さは比較の対象とはなりえない。流入量のピ ークが終了し, 低減に向かう期間に対する予測結果については, ii) のケースと比較してデータ蓄積した からといって必ずしも精度が向上したとは言えないようである。

以上のようにダム操作に際しては, 時々刻々入手できる降雨, 流量データを用いてモデルパラメーターの 表一 1 パラメーターの制約条件

\begin{tabular}{|c|c|c|c|c|c|c|c|}
\hline PARAMETER NO. & 1 & ** & $X 1$ (Q1) & LOWER = & 0.0 & UPPER = & 30.00000 \\
\hline PARAMETER NO. & 2 & $* *$ & $\times 2 \quad(02)$ & LOWER = & 0.0 & UPPER = & 30.00000 \\
\hline PARAMETER NO. & 3 & $* *$ & $X 3(M)$ & LOWER $=$ & 0.01000 & UPPER $=$ & 0.20000 \\
\hline PARAMETER NO. & 4 & $* *$ & $X 4(F)$ & LOWER $=$ & 0.00100 & UPPER = & 0.10000 \\
\hline PARAMETER NO. & 5 & $* *$ & $\times 5$ (A1) & LOWER = & 0.50000 & UPPER = & 1.00000 \\
\hline PARAMETER NO. & 6 & $* *$ & $\times 6 \quad(A 2)$ & LOWER = & 0.0 & UPPER = & 0.05000 \\
\hline PARAMETER NO. & 7 & ** & $x>(K)$ & LOWER $=$ & 0.00200 & UPPER = & 0.10000 \\
\hline
\end{tabular}

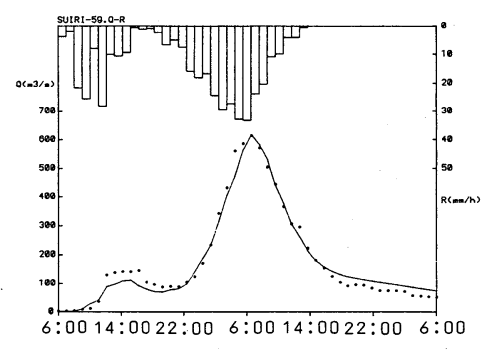

四-3 ダム流入量推定結果

$(\mathrm{N}=48)$

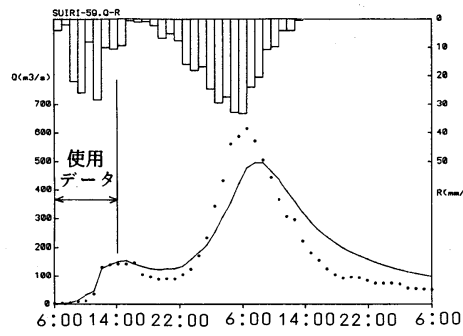

図-4(1) ダム流入量予測結果 $(N=8)$

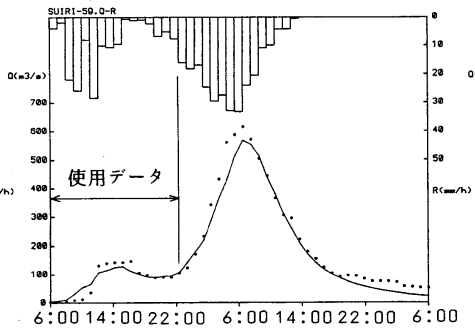

図-4(2) ダム流入量予測結果

$(N=16)$

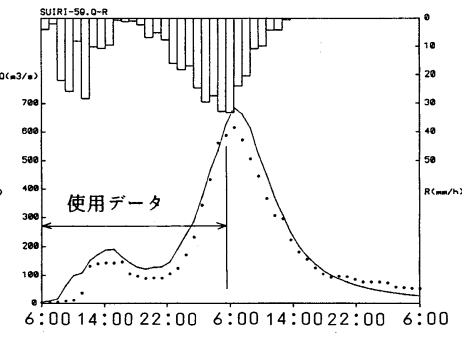

図-4(3) ダム流入量予測結果

$(\mathrm{N}=24)$ 
遂次更新を行ない, 予測精度を向上させていくという立場から, 使用するデータ数と予測精度の関係につい て考察してきた。ての結果, 降雨初期の段階ではデー夕数を蓄積するととにより飛翟的に将来流入量の予測 精度は向上していくが, 流量八イドログラフの立上り期間までのデータが入手できれば, それ以降のデータ 蓄積は以降の流入量予測に際してあまり効果を有しないてとが明らかとなった。

4. 準線形化を用いた予測モデルの拡張

\section{4-1 予測モデルの運用方法に関する考察}

ダム流入量予測等の実時間操作時において, 予測精度と同じように重要となるのは予測に要する所要時間 である。一般にての所要時間は短い程好ましく，たとえ十分な精度で予測が可能となったにせよ，それに要 する時間が長ければさしたる効果はなく, 逆に少々精度が悪くても所要時間が短い方が現場の管理者には好 まれるようである。本稿で用いた準線形化によるパラメーター決定アルゴリズムは，その利点として前述し たように，従来の試行錯誤を計算機内で自動的に行なうという点からかなりの所要時間の短縮を可能とした ものであるが, さらに所要時間の短縮という観点からその改良の余地を列挙すると次の 2 点を挙げるととが 可能と考えられる。

1) 予測に用いるデータ数を少なくするととにより微分方程式の数值積分に要する演算時間を短縮する。

ii ）データ更新毎に設定する初期近似解を前の期間で同定されたパラメーターを用いるととにより, パラ メーター収集に至るくり返し回数の短縮を図る。

以下では, このうちiについての検討結果を示すとともに, 使用するデー夕数により異なった值として同 定される洪水期間内でのパラメーターの時間的変化傾向について分析した結果を示す。

前揭図ー4(3)に示した降雨開始 24 時間データを用いた場合のダム流入量予測結果に対し, 予測精度を極 端に落とさないようにしてどの程度までのデータ更新が可能となるかを分析した結果が図－5(1)(2)である。 図一 5 (1) は, 上述の 24 時間データのうち, 降雨初期 8 時間のデータを捨て, 予測開始前 16 時間のデータ を使用した場合の結果であり, 同様に図-5(2)は降雨初期 16 時間のデータを捨て, 予測開始前 8 時間のデ 一夕を使用した場合の結果である。乙れらの図に示すようにデータ更新は予測に要する時間短縮に役立つ一 方, 用いるデータの取捨選択では予測結果にかなりの差異が生じるためデータ更新方法には十分な検討を要 するととがわかる。

本稿では，てのための検討として各予測ケースにおいて同定されたパラメーター值をもとに以下の立場か らデータ更新方法について考察し，予測に用いる妥当なデータ数として $N=16$ 時間という結論を得た。

すなわち, まずパラメーターは基本的には時間の関係として出水期間中は変化する(本モデルでは一定とし て取り扱っている）ものであるが，ての㑯向は例えば降雨初期とそれ以降といったような期間では大きな特 徵をもって変化すると考光, 表一 2 亿示すような出水期間中 3 期におけるパラメーター值を抽出した。ての 結果, 直接流出量を表現するタンク穴の乗数 $m$ については流量ハイドログラフがピークに達する $17 \sim 24$ 時間の間において最も大きくなる一方, 地下損失を表現する $K$ といてもての期間において最小となるてと が明らかとなった。流量ハイドログラフがピークに達するまでのてれらパラメーターの変化についてみると
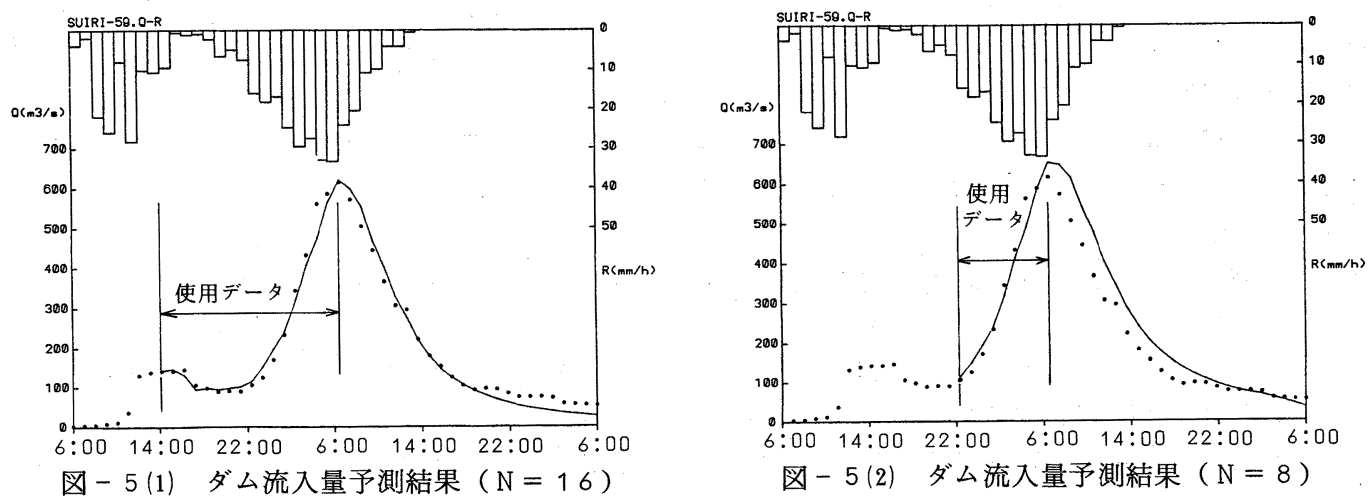
地下水損失を表現する

表 -2 パラメーターの同定結果

Kについては, 一般に 初期損失と言われてい る凹地貯留, 樹木遮断 等のため降雨初期には その値が大きく, 時間 の経過につれて低減す る傾向が現われている。

\begin{tabular}{|c|c|c|c|c|c|}
\hline 期間 & $m$ & $\varnothing$ & $K$ & $a_{1}$ & $a_{2}$ \\
\hline $\begin{array}{l}\text { 降雨初期 } \\
\quad \text { ( } 0 \sim 8 \text { 時間) }\end{array}$ & $7.2 \times 10^{-2}$ & $5.1 \times 10^{-3}$ & $6.8 \times 10^{-2}$ & $9.7 \times 10^{-1}$ & $0.6 \times 10^{-3}$ \\
\hline $\begin{array}{l}\text { 立上り期間 } \\
\text { ( } 9 \sim 16 \text { 時間) }\end{array}$ & $5.3 \times 10^{-2}$ & $4.9 \times 10^{-3}$ & $3.0 \times 10^{-2}$ & $7.6 \times 10^{-1}$ & $1.9 \times 10^{-3}$ \\
\hline $\begin{array}{l}\text { ピーク期間 } \\
\quad(17 \sim 24 \text { 時間 })\end{array}$ & $1.1 \times 10^{-1}$ & $5.2 \times 10^{-3}$ & $1.6 \times 10^{-2}$ & $8.3 \times 10^{-1}$ & $0.7 \times 10^{-3}$ \\
\hline
\end{tabular}
一方, 直接流出を表現する $m$ については, 降雨開始から 8 時間程度の時間遅れをもって最小值が現われてお り, 洪水初期における流出現象の複雑さの一端がうかがえる。流入量予測におけるデータ更新の際, 降雨初 期のデータを捨てて行なったケース（前掲図－5(1)）の予測結果が最も良好であった原因もてのためと考元 られる。また, 地下水流出を表現するめについては, 表一 2 に示すようにその変化は少なく, 洪水期間中一 定とみなせるようである。

\section{4-2 遅滞時間を考慮した洪水流出予測モデル}

貯留関数法は, 流域内の雑多な洪水流出機構を画一的に単一の模擬物理関数（貯留関数）に置き換えたも のであり,その計算式が流域の洪水流出現象と対照して比較的理解しやすい。てのため，その計算精度が洪 水の規模や洪水継続時間などによって異なってくるという指摘を有しながらも，種々の工夫がなされ建設省 を初めとして国内において広く適用され実用に供しているょうである。 こてでは，てのうち特に遅滞時間の 決定について検討した結果を示す。

前述したように準線形化手法は，未知パラメーターを含む非線形常微分方程式のパラメーター決定におい て特に有効である。このため従来貯留高と流出高との関係をもとに試行錯誤的に決定されていた遅滞時間の 取り扱いを次式に示すように未知パラメーターとして記述するてととした。

〈直接流出サブモデル $>$

$$
\begin{aligned}
& d S_{1}(t) / d t=r_{1}(t)-q_{1}(t) \\
& S_{1}(t)=K \cdot q_{1}^{p}(t+T l)=1 / m \circ\left\{q_{1}(t)+T l \cdot \dot{q}_{1}(t)+\frac{T^{2}}{2} \cdot \ddot{q}_{1}(t)\right\}^{p} \\
& \text { 乙てに, } T l \text { 遅滞時間 }(h r) \quad(\text { 他の記号は前掲式に順ずる。） }
\end{aligned}
$$

流量八イドログラフの推定結果を図ー6亿示す。前揭図ー 3 に示した推定結果は，流出量のピークが一致するよう事前に遅 滞時間を試行錯誤して $1 h r$ とみなし，降雨量データをその時間 だけ遅らせて計算したものであり，上記モデル式により同程度 の精度を維持しつつ, かつ遅滞時間の自動決定が可能となるこ とがわかった。

5. おわりに

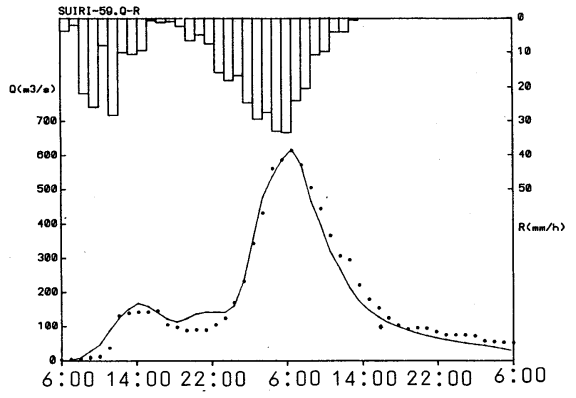

図- 6 ダム流入量推定結果 $(T l=0.94 \mathrm{hr})$

本稿は，準線形化によるパラメーター決定アルゴリズムを実際のダム操作を目的とした流入量予測モデル として, 効率的運用という観点からその有効性を明らかにしたものである。今後は, 流出機構の解明という 観点も踏まえモデルパラメーターの時間的変化を同手法を用いてさらに詳細に分析し, 流域の特性, 出水形 態等との因果関係を明らかにした上で, 流出量の将来予測に役立てたいと考える。最後に本稿の遂行にあた り, 論文作成の機会を与えて頂いた，秼日水コン 萩原良巳氏・中川芳一氏に謝意を表します。また，和田 芳樹氏の多大な協力に感謝します。

\section{〔参考文献〕}

1）萩原・中川・蔵重; 準線形化の河川計画への適用に関する研究, NSC研究年報, Vol.12, No.1, 1984 .

2）西原編；洪水予報，全建技術資料，全日本建設技術協会，1976.

3） 中川·森野·蔵重 ; 流域の土地利用形態を考慮した洪水流出解析(2), 第26 回水理講演会論文集, 1982 .

4）建設省土木研究所, 準線形化手法を用いた水循環モデルの機械的同定法, 土木研究所資料, 第 1911 号, 1983.

5) 藤原・佐々木; 貯留特性を利用した実用的洪水流出計算法, 第2 4 回建設省技術研究会報告, 1970 . 